Jerzy Oniszczuk

\title{
PONOWOCZESNOŚĆ: PAŃSTWO W UJĘCIU POSTNOWOCZESNYM (KILKA ZAGADNIEŃ SZCZEGÓŁOWYCH)
}

\section{Wprowadzenie}

Ważnym zagadnieniem jest to, o jakich cechach państwa i o jakim jego kształcie mówią poszukiwania dotyczące ponowoczesnej wizji państwa i prawa ${ }^{1}$. Próby ustaleń w tym zakresie sięgają do filozoficznych, kulturowych i socjologicznych refleksji. Niniejsze uwagi sygnalizują niektóre zagadnienia dotyczące ponowoczesnych odniesień do państwa.

Pojęcia postmodernizmu, postnowoczesności, ponowoczesności i ponowożytności najczęściej używane są zamiennie. Niekiedy wyraźnie zwraca się uwagę na różnice między zagadnieniami postmodernistycznymi i postnowoczesnymi, co czyni np. Zygmunt Bauman. Myśliciel ten uznał ostatecznie, że bardziej prawidłowe jest używanie pojęcia płynnej nowoczesności niż ponowoczesności². Najczęściej jednak pojęcia te wykorzystywane są w odniesieniu do współczesnych przekształceń społecznych, a także pojawiają się jako różne wątki i zjawiska w literaturze, estetyce, sztuce (malarstwo, film, muzyka), architekturze, socjologii czy filozofii. Można powiedzieć, że na postmodernizm składa się zbiór różnych poglądów. Jednak nie tyle próbuje się podać wyczerpującą definicję poszukiwań objętych tym pojęciem, ile wymieniane są różne cechy dlań charakterystyczne. Zgodzić się można ze spostrzeżeniem, że sam termin „postmodernizm” sugeruje, iż punktem odniesienia dla niniejszych uwag jest modernizm, a dokładniej, że chodzi o jego krytykę czy nawet odrzucenie. Spojrzenie to nabiera pewności, gdy okazuje się, że najogólniejsza pozytywistyczna ocena uznaje, że oświeceniowa wizja nowoczesnego człowieka i społeczeństwa załamała

1 J. Oniszczuk, Prawo $w$ debacie ponowoczesnej: oczekiwania wizji ponowoczesnych (kilka zagadnień), w: Administracja publiczna: między polityką, prawem i ekonomią, red. J. Osiński, Oficyna Wydawnicza SGH, Warszawa 2010, s. 367-378.

2 Z. Bauman, Wszystko co stałe, wyparowało, w: Idee z pierwszej ręki: antologia najważniejszych tekstów „Europy” - sobotniego dodatku do „Dziennika”, wybór tekstów C. Michalski, M. Nowicki, Axel Springer Polska, Warszawa 2008, s. 183. 
się. Należy tu przypomnieć, że charakterystyczna dla modernizmu i dla nowoczesności była wizja pozytywistyczna. W przypadku prawa wizja pozytywistycznoprawna łączyła wolę ustawodawcy z naukowymi osiągnięciami rozumu człowieka. Nawiązywała do nowoczesności przekonanej o możliwości odkrycia zasad rządzących naturą i kierowania za ich pomocą ludźmi.

\section{Ponowoczesność - idea unowocześniania jako takiego. Uznanie dla wolności cechą ponowoczesności}

Pojmowanie człowieka w społeczeństwie inspirowane myślą oświeceniową, rewolucją francuską czy też upadkiem dawnych państw miało na celu zastąpienie struktur niesprawnych, „zbutwiałych”, niezdolnych do działania i gwarantowania ładu strukturami nowymi, które zapewnią stabilność i pewność. Korzystająca $\mathrm{z}$ rozumu nowoczesność miała zapewnić trwały postęp, w miejsce przypadkowych decyzji miały pojawić się wybory racjonalne, przewidywalne, uwzględniające określony celowy ład. W ocenie Baumana upłynnienie wcześniejszego porządku miało charakteryzować np. postoświeceniowy Manifest komunistyczny. Wizja Marksa podejmująca sprawę stopienia tego, „co solidne i stanowe”, zawierała pogląd, że w miejsce to pojawi się nowa, ostatecznie trwała forma, wraz z którą zapanuje epoka wolności i zaniknie targająca ludźmi przypadkowość.

W przeciwieństwie do „solidnej nowoczesności”, kierującej się jakimś projektem, optymistyczną linią postępu, który rozwiąże problemy, obecna ponowoczesność nie tyle poszukuje lepszych, trwalszych struktur do realizowania jakiejś wizji rozwoju społecznego, ile charakteryzuje ją sam proces unowocześniania. Chodzi o to, aby dokonywało się ono jako takie. Udział w tym postępie opisywany jest jako pewien wyścig, którego jednym z wymiarów jest konsumeryzm, „polegający na szybkiej cyrkulacji” nabywania i pozbywania się, np. wymiany wczorajszego komputera na dzisiejszy, starego partnera na nowego. To upłynnianie tego, co trwałe i stabilne, przedstawiane jest bardziej jako narzędzie niż cel (charakterystyczny dla „solidnej nowoczesności”), albowiem istotne jest nie utrzymanie pewnej „pozycji w stałej strukturze, ale jej nieustanna regeneracja w ramach dynamicznej sieci”, będącej „macierzą” zarówno połączeń, jak i rozłączeń. Ta wersja rzeczywistości jest ważna dla ludzkich oczekiwań. Ludzkie jest bowiem zarówno pragnienie posiadania jakiejś pewności wzajemnych stosunków, trwałej podstawy, jak i obawa, że w sytuacji zmiany koniunktury mocne relacje społeczne i przywiązania będą 
obciążeniem, które uniemożliwi zachowanie właściwej pozycji czy udziału $\mathrm{w}$ wyścigu ${ }^{3}$.

Ocena stosunku ludzi do świata i społeczeństwa wydaje się obecnie podobna do obaw, które wzbudziły rezultaty oświeceniowego rozwoju nauk, a zwłaszcza zburzenie wcześniejszej wizji trwałego świata, pojawienie się relatywizmu, historycyzmu i sceptycyzmu co do pewności sensu świata. Stąd logicznym wydawałoby się odpowiednie sięgnięcie do myśli zaproponowanych w kantowskim projekcie odbudowania jakiegoś porządku społecznego. I rzeczywiście w pewnym zakresie tak się stało. Należy jednak zaznaczyć, że obecna sytuacja do odbudowania jest inna od tej, wobec której stanął Immanuel Kant. Ponowoczesność wyraża bowiem brak zaufania do „wielkich wizji” celowego przebudowywania świata, do nowej, wielkiej, uporządkowanej przyszłości (której „chore” próby realizacji niosły europejskie „-izmy”). A to z kolei rodzi relatywizm. Relatywizm Oświecenia (a nawet już XVI- i XVII-wieczny) wynikał z podważenia absolutnego, niezmiennego boskiego ładu średniowiecza. Ponowoczesność to także odstąpienie od dalekosiężnych planów ludzkości, ale też uznanie dla wolności jako dobra, które w hierarchii wartości jest ważniejsze niż bezpieczeństwo. Jednak rzeczywistość spowodowała, że ta wiara w wolność jako sens postnowoczesności jest obecnie kwestionowana.

\section{Ponowoczesność - globalizacja negatywna i pozytywna. Problem realizowania polityki państwowej}

Dla pełnej charakterystyki postnowoczesności istotna jest prezentacja tzw. globalizacji i związanej z nią pozycji człowieka w świecie ryzyka i mitu neoliberalnej gospodarki. Uwagi dotyczące granicy globalizacji próbuje sformułować m.in. Zygmunt Bauman, poprzez sprecyzowanie narzędzi poznawczych służących do zbadania znaczenia demokracji dla globalizacji.

W pierwszej kolejności bada obszar występowania zjawiska globalizacji. Zauważa, że nie występuje ono gdzieś daleko, lecz jest obecne wszędzie, stąd odróżnienie go od lokalności jest sprawą abstrakcyjną. Obydwa zjawiska bowiem wzajemnie się przenikają. Można więc powiedzieć, że globalizacja jest „wszędzie tutaj”. Ważne pytanie dotyczy przy tym cech dotychczasowej globalizacji, a zwłaszcza, czy odznacza się negatywnością, czy pozytywnością. Filozof prezentuje tu pogląd o negatywnym charakterze globalizacji. Tłumaczy to faktem, że dotychczasowa globalizacja

\footnotetext{
3 Ibidem, s. 185.
} 
wyrażała się w pokonywaniu granic, dzięki czemu doszło do zglobalizowania kapitału, rynku towarowego, informacji i przestępczości. Globalizacja ta dotyczyła sił, które "specjalizują się w dziurawieniu granic wszystkich instytucji lokalnych", a nie towarzyszyła jej przy tym "globalizacja instytucji prawnych, politycznych, sądowniczych, która mogłaby okiełznać zerwane ze smyczy siły usadawiające się w przestrzeni globalnej"4. Przy braku globalizacji instrumentów oddziaływania politycznego oznaczało to, że nadal dominowała zasada suwerenności terytorialnej. Mówiąc językiem systematyki - nie ukształtowała się globalizacja pozytywna, a zatem środki i sposoby kontroli dotyczące globalnych zjawisk gospodarczych i społecznych nie mają wymiaru globalnego.

Stan ten porównywany jest do sytuacji zaistniałej wraz z pojawieniem się gospodarki kapitalistycznej. Jej chaosu także nie można było uporządkować przy użyciu tradycyjnych instrumentów, czyli takich, które były przydatne do regulowania spraw grodu, gminy czy parafii ${ }^{5}$. W przypadku ludzi sprzed 200 lat „przestrzenie, jakie miały się scalić w państwa - narody, zdawały się [...] równie pełne zasadzek, jak dziś przestrzeń planetarna jawi się państwom narodowym”. Wyjściem z ówczesnych niepewności okazało się skonstruowanie trzech podstawowych instytucji: instytucji reprezentacji politycznej, instytucji stanowienia prawa - parlamentu i instytucji stosowania prawa - systemu sądowniczego. Instytucje te poradziły sobie $\mathrm{z}$ „przygodnością" zdarzeń i skoordynowały normy zachowania według założenia o potrzebie opanowania żywiołu XIX-wiecznego kapitalizmu oraz uczynienia świata względnie „przezroczystym” i „przewidywalnym” (określenia Baumana). Stanowisko osób przecierających ówczesne szlaki ku nowoczesności charakteryzowane jest jako wyrażające przekonanie, że „w świecie kierowanym rozumem i poruszanym jego narzędziami technicznymi katastrofy da się przewidzieć, a więc także im zapobiegać".

Wyobrażenia te Bauman postrzega jako mrzonki i porównuje do nich obecny świat ponowoczesny. Zauważa, że w początkach XIX wieku świat interesów uwolnił się spod reguł lokalnego społeczeństwa i jego środków nadzoru i pojawił się na „ziemi niczyjej”, podobnej do współczesnej „przestrzeni globalnej”. Stanu globalizacji filozof nie próbuje uzasadniać jako sukcesu określonej doktryny politycznej czy ideologii, np. neoliberalnej ideologii Miltona Friedmana. Przeobrażenia dotyczące

4 Z. Bauman, Laboratorium Europa, „Gazeta Wyborcza” 2009, 10-11 stycznia, s. 21.

${ }^{5}$ Z. Bauman zauważa, że w XVIII i XIX w. nastąpił rozpad tradycyjnych lokalnych zbiorowości, to jest wspólnot miejskich, parafii, cechów rzemieślniczych, gospodarstw domowych, grup sąsiedzkich, a więc takich podmiotów działania zbiorowego, na poziomie których „spotykały się polityka i władza - moc (Macht, pouvoir) osiągania celów”. Instytucje umożliwiające polityczną kontrolę mocy (władzy) „czyniły z tych wspólnot podmioty polityczne. Mariaż polityki i mocy na owym wspólnotowym poziomie rozpadł się i trzeba było 150 lat, zanim integracja polityki i mocy nastąpiła ponownie, tym razem na szczeblu państwa - narodu" (Z. Bauman, Wszystko co stałe, wyparowało, w: Idee z pierwszej ręki..., op.cit., s. 186). 
natury człowieka, ujęcia różnych zjawisk i relacji między nimi próbuje wyrazić za pomocą projektu „płynności”, którą charakteryzuje jako „substancję niezdolną do zachowania kształtu”. „Płynną nowoczesność” zatem definiuje Bauman jako „impuls obsesyjnego przeobrażania, »unowocześniania“ wszystkiego wokół”. Ale w tej nowej płynnej rzeczywistości jednostka staje wobec tworzenia „nowej przyszłości” zupełnie sama. Zdana jedynie na własne zasoby i talenty w świecie, który „nie sprzyja trwałości więzów społecznych ani ludzkiej solidarności”. Za Ulrichem Beckiem powtarza, że ludzie żyją w społeczeństwie ryzyka, co oznacza, że o jego zaistnieniu i zakresie jednostki nie będą wiedziały z własnego doświadczenia, tylko z opinii specjalistów. Ze względu na niemożność samodzielnej oceny przez jednostki prawdziwości ryzyka, w społeczeństwie ryzyka człowiek musi wierzyć opinii specjalistów. Stan ten opisywany jest jako raj dla różnych oszustów, którzy nie obawiając się zarzutu kłamstwa, bagatelizują realne zagrożenia bądź pozwalają sobie na straszenie różnymi rojeniami.

W przypadku władzy, nawet w krajach uznających się za demokracje, powyższa sytuacja może okazać się niezwykle przydatna. Taka władza może wybiórczo informować obywateli np. o szczególnym zagrożeniu dla całej ludności państwa płynącej z udaremnionych zamachów. W rezultacie obywatele nie tyle mają oceniać politykę rządu w różnych dziedzinach, np. zdrowia, kultury czy w sektorze socjalnym, ile wyrażać wdzięczność za zapewnienie im indywidualnego bezpieczeństwa. Na koncepcji strachu zbijany jest kapitał polityczny, stąd legitymacja władzy przesuwa się z obszaru zbiorowego zabezpieczenia społecznego w kierunku bezpieczeństwa osobistego. Państwa nie potrafią przedstawiać obywatelom nowych, rozsądnych propozycji politycznych, dlatego wybory nie prowadzą do nowych wizji, tylko sprzyjają postępującej apatii społecznej.

Wobec powyższego za pozytywną nie może być postrzegana skrajna neoliberalna koncepcja uznająca jedynie zasady wolnorynkowe i myśl, że lekarstwem na problemy ludzkie są „,rozwiązania prywatne”. Jak zauważa Bauman, neoliberalizm odrzucił liberalne wartości, takie jak wolność osobista, prawo do samostanowienia i odmienności oraz prawo do godności i szacunku. Filozof prognozuje, że neoliberalne praktyki będą się rozwijały, dlatego przy pogłębianiu się nierówności społecznej krytyka z pozycji np. solidarnościowych będzie orientowała się ku „wolnościowemu rdzeniowi idei liberalnej”. W zglobalizowanym świecie wyjście ze złego korytarza, w który wpędza ludzkość neoliberalny rynek bez wartości, Bauman widzi w rozwoju prawdziwej debaty politycznej i w poważnym potraktowaniu koncepcji, że „wszyscy bylibyśmy bogatsi, gdyby wszystkim pozwolono uczestniczyć we wspólnocie, nikogo nie pomijając. Wszyscy zyskalibyśmy na sile, gdyby każdy z nas, a nie tylko nieliczni, mógł czuć się bezpieczny". Wreszcie filozof uznaje, że tzw. obiektywne wskaźniki 
dowodzą trafności poglądu, że koniecznym warunkiem modernizacji jest „dążenie do spójniejszej socjalnie wspólnoty”. Jeżeli chodzi zaś o konstrukcję solidarności wspólnoty, to nie sytuuje jej w obszarze litości i filantropii, ale odnajduje ją w „poczuciu wspólnej odpowiedzialności moralnej za godność każdego ze swych członków, za jego prawo do stanowienia, a także wolność od upokorzenia ${ }^{6}$.

Pojawienie się globalizacji, jako nowego wymiaru międzynarodowego, spowodowało, że realizowanie polityki w dzisiejszym państwie jest dużo trudniejsze. $\mathrm{W}$ przypadku państw zasadniczym instrumentem jest prawo państwowe, chronione przymusem i egzekwowane za pomocą siły organów państwa. Dawna tradycja europejska (mająca u podstaw myślenie tomistyczne) dostrzegała konieczność sprawiedliwego działania określonych podmiotów władzy (uzasadnienie legalności działania). Organy te miały działać na rzecz dobra wspólnego. Z kolei tradycja państwa prawnego na pierwszy plan wydobyła znaczenie procedury, formy prawnej przesądzającej o władzy i jej legalności. W warunkach globalizacji zanika wcześniejsze znaczenie władzy wynikające $z$ treści czy formy jej konkretnych organów. W ich miejsce pojawia się system władzy rozproszonej w sieci. Brak tu np. tradycyjnego wytwarzania władzy, mocy w drodze politycznych wyborów obywateli państwa. Władza przechodzi do struktury, która rządzona jest za pomocą procedur. Sprawność działania całego systemu wymaga odpowiednich relacji między jego instytucjami, wymaga zbudowania struktur o jakości odpowiadającej globalnej sieci. Problematyczne staje się działanie postmodernistycznego, w znaczeniu globalnego, świata władzy nie tylko w zakresie tworzenia i zachowywania sprawności własnego systemu. Równie dyskusyjne jest także etyczne uzasadnienie jego działania zarówno w wymiarze ogólnym (dobro zbiorowe, sprawiedliwość), jak i jednostkowym (gwarantowanie podmiotowości moralnej jednostki, utrzymania poczucia słuszności działań struktury wobec człowieka).

\section{Postmodernizm jako rezygnacja z odniesień ideologicznych. Pokoleniowa postawa postmodernistyczna}

Postmodernizm często traktowany jest jako rezygnacja $\mathbf{z}$ odniesień ideologicznych. Na przykładzie konkretnych polityków z początku XXI w. i różnych

\footnotetext{
6 Z Bauman, W fortecach nowoczesności, rozmowa Łukasza Gałeckiego, „Gazeta Wyborcza” 2006,
} $5-6$ sierpnia. 
względem nich oczekiwań wypowiadane są popularne oceny, że polityk ma być przywódcą zorientowanym na zasadnicze problemy państwa. Jednocześnie zauważa się, że politycy pojawiają się jako bohaterowie wyobraźni społeczeństwa, jako celebryci, medialni aktorzy, którzy proponują „cos'” w nowej, atrakcyjnej formie, przedstawiają nową narrację. Polityków ostatnich lat (np. Sarkozy) ukazuje się jako rezygnujących z podążania za wskazaniami określonej ideologii. Ten swoisty pragmatyzm charakteryzowany jest jako postmodernizm, zaś postawa postmodernistyczna ukazywana jest jako taka, której obce są jakieś przekonania polityczne.

Podejście, które zakłada, że postmodernizm oznacza brak poglądów, brak sporów o cokolwiek, a zwłaszcza, że cechuje go relatywizm, przypisywane jest starszemu pokoleniu. Natomiast poprawne pojmowanie postmodernizmu, u podstaw którego jest niezbyt właściwy podział binarny starsi (bardziej dogmatyczni) - młodsi (plastyczniejsi), ma wyrażać myśl, że chodzi o „kres dogmatycznego rozumu, kres, który prowadzi przede wszystkim do zachwiania epistemologią. Już nie ma żadnego sądu, który można wypowiedzieć z pełnym przekonaniem epistemologicznym". Takie ujęcie postmodernizmu odrzuca zarówno aprobatę „obojętnej wielokulturowości”, jak i brak posiadania przez ludzi utrwalonych, wyraźnych poglądów. Niemniej te różne poglądy, nawet mocne, trwałe, nie są gwarantowane pewnością epistemologiczną, co oznacza, iż nie ma czegoś takiego jak uniwersalne czy absolutne kryterium rozstrzygania. I w tym ujęciu kryterium decydowania postmodernizm odnajduje w człowieku, który ma być gwarantem swego stanowiska, poglądu.

Wizja ta ma, co do istoty, pozostawać w konflikcie z pojmowaniem postmodernizmu przez starsze pokolenie. Dowodem na to ma być pogląd, że osoby starsze cechuje fundamentalizm, który nawet gdy zastępowany jest antyfundamentalizmem, to i tak wyrażany jest $\mathrm{w}$ fundamentalny sposób. Bowiem u podstaw myślenia starszych leży wiara czy też przekonanie o obecności bądź istnieniu prawdy. Tymczasem postmodernizm młodszego pokolenia nie wyraża takiej wiary, albowiem jest ono przekonane o niemożliwości ostatecznego uzasadnienia wyznawanej idei czy poglądu. W tym epistemologicznym podejściu nie ma mowy o relatywizmie wymiaru moralnego. Relatywizm, o którym mowa, rozpatrywany jest jedynie w sensie metodologicznym. W tej charakterystyce postmodernizm odczytywany jest jako anarchizujący starsze pokolenie, a miałoby to następować poprzez fakt, że starsi nie nabyli sprawności dystansowania się wobec tego, co wypowiadają, gdyż „nie mają świadomości gry, w której uczestniczą". U starszych pojawia się fundamentalizm, gdyż oni nie widzą gier, co oznacza np. że uczestnicząc w polityce, podejmują „chamskie bijatyki, kto kogo ze stołka zrzuci, oni nie rozumieją gier komunikacyjnych, nie rozumieją społeczeństwa sieciowego, żyją wedle jakichś dawnych hipostaz: inteligencja, nie inteligencja, robotnicy, demokracja, liberalizm.... 
Przeciwną postawę ma zajmować młodsze pokolenie, które cechuje świadomość udziału „w bardzo skomplikowanej kulturowej grze"7. Świadomość ta oraz umiejętność dystansowania się wobec gry powodują, że młodsze pokolenie jest zdecydowanie bardziej plastycznym podmiotem politycznym. Takie społeczeństwo postmodernistyczne odczytywane jest jako „bardziej autorefleksyjne, a społeczeństwo refleksyjne jest innym społeczeństwem niż społeczeństwo naiwne”. Pod koniec pierwszego dziesięciolecia w Polsce ocena jest taka, że życie ludzkie przebiega w społeczeństwie, w którym dominują "naiwniacy”, to jest ludzie, którzy nie potrafią „spojrzeć z zewnątrz na swoje gry". Można powiedzieć, że takie ujęcie postmodernizmu pozostaje nieco w duchu kantowskim czy też antycznym, który człowieka moralnego czynił miarą wszechrzeczy. Człowiek postmodernistyczny nie jest relatywistą, jest natomiast odpowiedzialny sam za siebie, co oznacza, że nie zdaje się na żaden absolut teologiczny czy determinizm mechanicznego rozumu (jakiejś powszechnej zasady oczekiwań racjonalnych itp.). I tu pobrzmiewa jakaś nuta wyobraźni nietzscheańskiej.

\section{Władza postnowoczesna}

\subsection{Władza postpolityczna. Niedoskonałość demokracji}

Wśród podstawowych przymiotów każdej władzy, także demokratycznej, jest jej zdolność urzeczywistniania swojej woli. Podstawową kwestią jest zatem ustalenie tego, co powinno cechować władzę państwową, aby mogła realizować swoje cele i zadania. W tym zakresie wypowiadany bywa najogólniejszy pogląd, że władzy musi być „niezbędna ilość”, aby rządzącym „zapewnić wolne od kompromitacji trwanie”, zaś obywatelom „minimum satysfakcji z rządu”. Władza musi dysponować odpowiednimi narzędziami, to jest $\mathrm{z}$ jednej strony właściwą administracją ${ }^{9}$ a $\mathrm{z}$ drugiej obszarami wrażliwymi z punktu widzenia potrzeb i interesów obywateli (np. dostarczania „satysfakcji” za płacone podatki). Należy tu odnotować, że na skuteczność władzy składa się także możliwość jej przymusowego działania.

K. Dunin, Tu nie było lewicowej hegemonii, rozmowa z Cezarym Michalskim, Dodatek „Europa”, „Dziennik” 2007, 8 grudnia, s. 5.

8 Ibidem.

9 R. Krasowski, Gdzie jest władza? (Przekonanie o istnieniu zakulisowych sił było zastępcza forma, w jakiej Polacy przeżywali słabość państwa), w: Idee z pierwszej ręki..., op.cit., s. 297. 
W powyższych zdaniach zwrócono uwagę na sprawę ilości i skuteczności władzy oraz na kwestię narzędzi jej sprawowania. W sposób wyraźny widoczne jest to wówczas, gdy niemal powszechnie dostrzega się brak posiadania przez państwo instrumentów koniecznych do sprawowania władzy, np. w warunkach kryzysowych. Wówczas wręcz wprost mówi się, że państwo „bezmyślnie oddało” narzędzia władzy i godziło się z tym, że ,instytucje władzy zostają zredukowane do teatru, jaki jest odgrywany przed oczami obywateli” zarówno przez rządzących, jak i opozycję ${ }^{10}$. Wspomniany stan upadku władzy może mieć miejsce w sytuacji oddania jej narzędzi np. „w ręce komercyjnych agencji i funduszy (np. służba zdrowia)”, struktur ponadpaństwowych (np. Wspólnota Europejska) czy podmiotów gospodarki światowej ${ }^{11}$. Wobec powyższego dowodzi się istnienia sporej nieaktualności w postrzeganiu arbitralnych, tradycyjnych cech władzy. Archaiczny model władzy politycznej pojawia się zatem w postnowoczesnych warunkach, co oznacza, że zachodzi jakieś „swobodne przekraczanie granicy lokalnej polityczności i globalnej pospolityczności”. W układzie tym władza nie posiada już jednoznacznych hierarchii. Kwestią dyskusyjną jest zatem „zdolność do przekraczania granicy tradycyjnej, już bezsilnej i niefunkcjonalnej władzy politycznej, i tej nowej, postpolitycznej władzy instytucji i procedur"12.

Wspomniana demokracja opisywana jest bardzo często jako niedoskonała $\mathrm{w}$ wypełnianiu swojej misji (obietnicy). Wizja przyzwoitej demokracji traktowana bywa raczej jako jedno $\mathrm{z}$ wielu oczekiwań pewnej doskonałości, jakiś mit, albowiem warunki do jego spełnienia rozmywają się. Współcześnie więc w zmierzchających warunkach postnowoczesnych i wschodzących czasach postpostnowoczesnych istotna jest wizja cech nowej, z założenia adekwatniejszej demokracji i obsługującego ją prawa. Czy więc np. w nowej demokracji rynkowej, z uwagi na osłabienie kluczowej roli zaufania jednostki i lojalności państwa, uformuje się jakaś nowa prawna koncepcja racjonalności albo skutecznej ekonomiczności czy konwencjonalności, kierującej się np. ku instynktowi samozachowawczemu ${ }^{13}$ ?

Odnotowuje się niekiedy, że jednym ze zjawisk wpływających na dzisiejsze działanie narodów Europy poza globalizacją jest trudność społeczeństwa z określeniem samego siebie. Powoduje to $\mathrm{m}$. in. że rządy nie są postrzegane jako przedstawiciele wszystkich. Stan ten jest źródłem problemów decyzyjnych, wyborów politycznych. Rzeczywistość ta różni się od sytuacji z epoki nowoczesnej, w której zmilitaryzowane

10 J. Staniszkis, Miękki premier, niezorientowany prezydent, słabi ministrowie - Polska wobec kryzysu, „Dziennik” 2008, 1 grudnia, s. 18.

11 R. Krasowski, Gdzie jest władza?, w: Idee z pierwszej ręki..., op.cit., s. 303.

12 J. Staniszkis, Prawda i fałsz polskiej polityki, w: Idee z pierwszej ręki..., op.cit., s. 394.

13 M. Zirk-Sadowski, Postmodernistyczna jurysprudencja?, w: Ponowoczesność, red. M. Błachut, Kolonia Limited 2007, Wrocław 2007, s. 24, 41; A. Kozak, Postponowoczesna koncepcja prawa, w: Ponowoczesność..., op.cit., s. 76-77. 
narody cechowała pewna wyrazistość, przedstawiały jasno pewien interes ogólny i hierarchię społecznych wartości oraz żądały od człowieka poświęcenia. Takich cech nie dostrzega się we współczesnych narodach europejskich, które często charakteryzuje ograniczenie do wymiaru ekonomicznego ${ }^{14}$. W każdym razie dotychczasowa ocena jest taka, że większość tzw. społeczeństw rozwiniętych żyje w państwach narodowych ${ }^{15}$, które stają przed problemami, na które wpływa globalny rynek. Wyrażane nawet bywają poglądy, że w przyszłości państwo narodowe może przestać być podstawą społecznej solidarności i politycznej demokracji ${ }^{16}$.

Nieco skromne pod koniec XX wieku uwagi dotyczące globalnych zmian, pod koniec pierwszego dziesięciolecia XXI wieku przybrały już postać mocnych twierdzeń, że zachodzące zmiany są wywołane, a w rzeczywistości tylko przyspieszone czy też symbolizowane przez kryzys finansowo-gospodarczy z 2007 roku. Wobec powyższego nie brzmiały już zatem pusto przypuszczenia, że kończy się pewna epoka i ma miejsce dynamiczne wejście w jakąś, mniej lub bardziej wyobrażoną, wizję cywilizacji XXI wieku. Wykształcanie tej wizji następuje w warunkach, gdy ekonomia odnotowywała głównie sukcesy, poddając swojej dominacji coraz to nowe obszary. Następuje w warunkach, gdy np. siła militarna zastępowana jest siłą ekonomiczną, a argument siły racji umysłowej i fizycznej zastępuje argument ekonomiczny.

\subsection{Rozumienie władzy w Europie w sytuacji istnienia państw prenowoczesnych, nowoczesnych i postnowoczesnych na świecie}

Sukces Europy w postaci pokojowego współdziałania państw w ramach wspólnoty wiązany jest $\mathrm{z}$ uznaniem większej wartości współpracy, soft power, miękkiej dyplomacji oraz poszanowania praw człowieka. Zamiast pomysłu o podboju innego państwa, który faktycznie okazuje się dla wszystkich rujnujący, pojawiła się myśl o „przeciąganiu” go w stronę naszych uzasadnień i wizji rozwiązywana trudnych spraw. Cierpliwość i delikatność w relacjach oraz swoista „słabość" niedookreślonej Europy, która nie jest charakterystyczna dla potęg, mają obecnie umożliwiać Europie przemianę świata zewnętrznego w zaprzyjaźniony. Europa opiera się na wartościach, które niekiedy różnią się od wartości innych państw, co powoduje, że relacje z nimi należy budować bardziej na interesach czy handlu, bo to i tak jest to „zawsze lepsze niż dokonywanie inwazji militarnej”. W każdym razie, gdyby politykę prowadzić tylko w oparciu o wartości, to Europa musiałaby „odrzucić każdego, kto tych

\footnotetext{
14 M. Gauchet, Prawica chce zmian, lewica je blokuje, w: Idee z pierwszej ręki..., op.cit., s. 98.

$15 \mathrm{Ph}$. Bobbitt, Hegemonia i rynek, przeł. Tomasz Biedroń, w: Dodatek „Europa”, „Dziennik” 2008, 17 maja.

16 R. Bugaj, Przyszłość Sojuszu: ta czaszka się nie uśmiechnie, „Dziennik” 2008, 21-22 maja.
} 
wartości nie podziela”, to zaś ostatecznie „musi doprowadzić do konfliktu”. Wobec tego wspólnym celem różnych państw pozostaje zachowanie wzajemnego bezpieczeństwa, zakłócanego wówczas, gdy jedno z nich okazuje się „krajem ekspansywnym militarnie" (Robert Cooper) ${ }^{17}$.

Taka wizja Europy stoi w sprzeczności ze stanowiskiem o istnieniu ponowoczesnego państwa europejskiego (w którym pierwszeństwo mają prawa jednostki, a nie interes państwowy) w świecie, w którym równocześnie występują państwa prenowoczesne i nowoczesne. $\mathrm{W}$ tej sytuacji pozostawanie wyłącznie państwem ponowoczesnym, z jego wizją miękkiej władzy, powoduje brak efektywnego „radzenia sobie” nie tylko $\mathrm{z}$ dwoma pozostałymi typami państw, ale zwłaszcza $\mathrm{z}$ tzw. państwami upadłymi; do tego bowiem konieczne jest dysponowanie również twardymi mechanizmami (Jacek Saryusz-Wolski) ${ }^{18}$. Z poglądów o ponowoczesnym charakterze Europy wyłania się ocena, że bardziej stabilizująca dla świata jest wizja Unii Europejskiej niż systemów wojskowych, np. NATO. Tymczasem, w opinii niektórych, europejskie poszukiwanie pojmowania władzy odchodzi od wizji budowanych przez myślicieli XIX wieku i dąży w kierunku rozumienia cechującego kulturę azjatycką, tj. „zrozumienia życia w konflikcie jako czegoś normalnego" ${ }^{\prime 1}$.

\subsection{Osłabienie władzy państwa narodowego po wejściu państw do struktur ponadnarodowych}

Globalny rynek to nie jedyny poważny powód słabnięcia tradycyjnej XIX- i XX-wiecznej wizji państwa narodowego oraz jego mechanizmu władzy ustawodawczej, wykonawczej i sądowniczej. Władza ta bowiem osłabia się w większym stopniu w następstwie wchodzenia państw do struktur ponadnarodowych o charakterze Wspólnoty Europejskiej, które przejmują szereg funkcji organów państwa. Przecież $\mathrm{w}$ politycznych wyborach przedstawicieli i urzędników państwa trzeba liczyć się $\mathrm{z}$ władzą pozapaństwowych instytucji i struktur, być w zgodzie $\mathrm{z}$ ich decyzjami albo dawać im przewagę w przypadku konfliktu z regułami państwa. Uważa się, że w przypadku Unii Europejskiej 70-80\% prawa nie pochodzi już od państwa narodowego. Pojawia się zatem pytanie, jak w tej sytuacji obywatele mają ufać państwu i jego prawu, skoro realnie nie ma ono wpływu na $100 \%$ prawa stanowionego i stosowanego. W każdym razie prawo krajowe w znacznym stopniu ma charakter wykonawczy, musi liczyć się albo uwzględniać jako regulacje „wyższe”: prawo WE, prawa

17 R. Cooper, Czy Unia przetrwa w XXI wieku?, Dodatek „Europa”, „Dziennik” 2008, 8-9 listopada, s. 2.

18 J. Saryusz-Wolski, ibidem, s. 2.

19 J. Staniszkis, Czy Polska przetrwa w Europie?, Dodatek „Europa”, „Dziennik” 2007, 3 listopada, s. 3. 
organizacji uniwersalnych (np. ONZ), regionalnych (np. Rada Europy), tzw. prawa człowieka, prawo i porozumienia wielkich firm międzynarodowych itd. W każdym razie państwowo-polityczne „wybory” i rozstrzygnięcia muszą uwzględniać inne systemy wartości, inną hierarchię celów czy funkcji.

Jakiego zatem zaufania od obywatela może oczekiwać takie względnie samodzielne demokratyczne państwo prawne, skoro nie może być w stosunku do niego wystarczająco lojalne, skoro nie może wypełniać obietnic, a jego ministrowie nie są wykonawcami ustaw państwa, ale bardziej „przekaźnikami” zewnętrznych, ponadpaństwowych wskazań, zwłaszcza rynków przemysłowych i kapitałowych? Obywatele np. otrzymują niskie emerytury, które nie pozwalają na pokrycie stałych opłat, podstawowych leków, najtańszego utrzymania. Skarżą zatem wysokość emerytury, tj. pozywają krajowe organy rentowo-emerytalne czy organy państwa do sądów państwowych, które z kolei skargi oddalają. Skargi te mają szansę trafić do Trybunału w Luksemburgu. Jeżeli orzeczenie sądów w Strasburgu czy Luksemburgu utrzyma wyrok krajowy, to będzie to tylko kolejny dowód na upadek obietnicy państwa narodowego. Jeżeli Luksemburg znajdzie sposób na wykazanie dodatkowych obowiązków państwa, których nie będzie mogło ono realnie spełnić, to też dowód na bankructwo pięknej idei państwa narodowego, realizującego ideę solidarności społecznej i aktywności politycznej obywateli, władzy za dobrobyt. Zatem świetne zasady formalnego państwa prawnego mogą mieć tylko książkowy sens, podczas gdy ludzie nie mają dochodów nie tylko na dobre czy przyzwoite życie, ale nawet na podstawową egzystencję. Może nie będzie to wystarczający argument na rzecz akceptacji przez obywateli jakiejś innej demokracji, np. rynkowej, ale skoro obietnice dotychczasowej demokracji upadają, to możliwość opowiedzenia się za nową wizją większości obywateli, zwłaszcza tych aktywnych zawodowo, aby nie znaleźć się w sytuacji wspomnianego emeryta „bez szans”, jest ogromna. Może zwyciężyć hasło: „Lepsza jakakolwiek szansa niż nic".

Postrzeganie Unii w postaci sieci reguł i zarządzania prowadzi wielu myślicieli do oceny, że ogranicza się polityczne znaczenie państw w postaci bytów politycznych i że ich zasadnicza rola sprowadza się do „administrowania, dopasowywania społeczeństwa i instytucji do wymogów poszczególnych państw, tak aby jak najwięcej skorzystać”. Nadto mówi się, że Europa wkroczyła „w fazę postnowoczesną, przezwyciężając stare kategorie suwerenności, polityki i narodowego interesu”. Zwłaszcza to drugie stwierdzenie wywołuje polemiki, a nawet dostrzega się powrót do politycznej roli państw, przy czym nie chodzi tu już o XIX-wieczną wizję „,autonomicznych państw budujących między sobą kruchy układ równowagi" ${ }^{20}$. W każdym razie

20 M.A. Cichocki, Bruksela nas wyzwoli, „Rzeczpospolita” 2004, 16 stycznia. 
zapotrzebowanie na idee pojawia się zwłaszcza w okresie wyraźnych kryzysów i zaburzeń, gdy biurokratyczne instytucje i struktury ostatecznie zawodzą.

Jeżeli ta myśl jest trafna, to zapewne ważne idee są jeszcze bezpieczne, jeśli sprawy Europy widzieć przez pryzmat poglądów Guy’a Sormana. Ocenia on, że zorganizowana w Unii Europa jest wielkim współczesnym sukcesem, takim, jak zakładali to ojcowie założyciele („żyjemy w pokoju, nie ma inflacji, możemy się swobodnie przemieszczać"). Dostrzega on tylko kryzys wywołany pomysłem biurokracji, aby natychmiast zbudować „wielki naród europejski i dzięki temu załatwiać wszystkie sprawy we własnym gronie"21. Państwo narodowe w Europie jako wytwór historyczny i polityczny umożliwiło ukształtowanie się współczesnej demokracji. Jednocześnie stawiane jest pytanie (na razie bez poważnej odpowiedzi): czy może mieć miejsce coś takiego, jak demokracja postnarodowa?22. Pytanie to jest o tyle ważne, że uniformizuje oddziaływanie europeizacji i globalizacji i sprzyja odtwarzaniu różnych nacjonalizmów ${ }^{23}$.

\section{Postpolityka w demokracji cechą postnowoczesności}

Wizerunkowe działania, „przymiarki”, zwracanie uwagi na dobrze zawiązane krawaty ukazywane są jako swoiste symbole postpolityki, która wyraża się bardziej w pewnej formie, języku, wizerunku polityka niż ideologicznie konfrontowanej treści. Istotą tego zjawiska w demokracjach liberalnych okazuje się prowadzenie polityki, zwłaszcza rządowej, która unika powiązania z wyraźną ideą. Stąd łatwo dochodzi do rozmywania, np. nastawień prawicowych, lewicowych czy centrowych. Wpływ na ten stan miał z jednej strony upadek w latach 90 . tzw. bloku państw socjalistycznych w Europie, a z drugiej - wiele afer dotyczących partii politycznych, zwłaszcza o charakterze finansowo-korupcyjnym, które je skompromitowały.

Pogląd, że tradycyjna polityka wsparta na określonej ideologii i interesach klasowych traci siłę, albowiem zaniknęła tradycyjna lojalność klasowa czy ideologiczna wyborcy, przypisuje się Sylvio Berlusconiemu. Po upadku Związku Radzieckiego w latach 90. spory w łonie włoskiej lewicy spowodowały jej marginalizację, ale również doszło do upadku rządzącej skorumpowanej chadecji. Berlusconiego nie cechowała jakaś ideologiczność, ale pragmatyzm służący utrzymaniu władzy i realizacji

${ }^{21}$ G. Sorman, Polska broni Europy przed banalnościa, rozmowa z Maciejem Nowickim, Dodatek „Europa”, „Dziennik” 2007, 22 września.

22 A. Finkielkraut, Europa nie narodziła się w Auschwitz, w: Idee z pierwszej ręki..., op.cit., s. 56.

23 V. Havel, Rewolucjo ducha, przyjdź, „Gazeta Wyborcza” 2008, 15-16 listopada, s. 18. 
egoistycznych interesów ${ }^{24}$. Zrozumienie zjawiska postpolityki związane jest zatem z przemianami politycznymi w Europie i kryzysem tradycyjnych partii politycznych. Ta swoista uniwersalizacja dokonana za pomocą zwinięcia sztandarów ideowych i rozmycia tożsamości partii okazała się dosyć skuteczną praktyką zarządzania, albowiem w ostatnich latach XX w. i w pierwszym dziesięcioleciu XXI w. społeczeństwa preferowały w większym stopniu niejasną centrowość kosztem wyraźnych idei lewicowych czy prawicowych.

Niekiedy postpolityka, która nie polega na wyraźnym ocenianiu ani piętnowaniu praktyk nieakceptowalnych z punktu widzenia praw człowieka, opisywana jest jako swoisty cynizm. Ocena ta nie godzi się z przyznawaniem tej postawie cechy pragmatyczności, gdyż w takiej sytuacji dochodzi do rozmywania właściwego znaczenia tego pojęcia. Wśród przykładów projektów czy działań wpisujących się w postpolitykę wymieniano Blairowską tzw. trzecią drogę lub praktykę polityczną prezydenta francuskiego Nikolasa Sarkozy’ego. Ten ostatni próbował realizować sprzeczne role, przekraczając też ideologiczne bariery (ideologiczny „stan nieważkości”). W przypadku postpolityki, którą cechuje poruszanie się między sprzecznościami ideologicznymi, ma też miejsce wspomniane manipulowanie opinią publiczną, zwłaszcza gdy społeczeństwo przestało dostrzegać różne sprzeczności. W świecie postpolitycznym dochodzi zatem do stanu, gdy - jak zauważa Emmanuel Todd - „wielkie systemy stanowiące ramy dla życia społecznego - katolicyzm, komunizm, socjaldemokracja - nie mają już najmniejszego znaczenia. Znaleźliśmy się w stanie absolutnej nieważkości: wszystko stało się możliwe"25.

W sytuacji zanikania politycznych zróżnicowań postpolityka okazała się swoistym środkiem leczniczym na osłabienie sposobów przedstawiania różnych stanowisk i interesów grupowych. Postpolityka pojawiła się jako coś zbliżonego do centrum (np. wspomniana „trzecia droga”). Pierwsze dziesięciolecie, coraz bardziej postpolityczne, nie oznaczało nagłego zatarcia dawnych podziałów, zwłaszcza o charakterze moralnym. Przy pewnych okazjach pojawiały się np. próby przypominania, czym był komunizm ${ }^{26}$. Pojawiały się też krytyczne oceny polityki liberalnej zapobiegającej zacieraniu się zróżnicowań. Dowodzi się, że świat postpolityki, który na początku XXI w. pojawił się w różnych państwach (np. Francja, Włochy, Polska, Rosja czy USA), miał wiele wersji, chociaż wspólną cechą było różnorodne

\footnotetext{
24 A. Stille, Berlusconi na ruinach polityki, rozmowa z Maciejem Nowickim, Dodatek „Europa”, „Dziennik" 2009, 2-3 maja, s. 2.

25 E. Todd, Sarkozy wprowadził Francję w stan ideowej nieważkości, Dodatek „Europa”, „Dziennik” 2009, 25-26 kwietnia, s. 2-3.

${ }^{26}$ W opisie Jadwigi Staniszkis (Niespetnione marzenie, „Rzeczpospolita” 2005, 26-27 lutego) komunizm stanowił mechanizm „brutalny w swym systematycznym pomniejszaniu ludzi, rządzeniu przez eksploatowanie słabości”.
} 
manipulowanie ideami i znaczna niezależność rządzących od ideologicznych zobowiązań.

W postideologicznym świecie logika lewicy i prawicy straciły ważność. Temu zanikowi lewicowych i prawicowych kryteriów oceny rządów towarzyszyło istotne osłabienie zdolności ludzi do odróżniania nieprawdy od prawdy, rzeczy moralnie wartościowych od nagannych. Na pierwszy plan wysunęły się marketingowe działania rządów przypominające te ze sfery show biznesu. Uważa się, że wraz ze społeczną akceptacją dla postpolitycznej aktywności rządów wzrosła swoboda i zwiększenie niezależności władzy wykonawczej od ocen ideowych. Postpolityka była też często traktowana jako mechanizm uczestniczenia w polityce oparty na innych zasadach niż w przeszłości, kiedy działania polityczne cechowała pewna twardość i powaga.

Wśród mechanizmów jej sprawowania szczególne miejsce znalazła praktyka (technika) negocjacji, ciągłej dążności do porozumienia. W tym zakresie postpolityka ma charakter tzw. miękkiej polityki. Jednak ocenia się, że jakaś „terapeutyczna” polityka łagodzenia społecznych napięć nie zapobiegnie w przyszłości głębszym sprzecznościom i konfliktom. Charakterystyczna jest tu postawa centrowego polityka Baraka Obamy skierowana na „racjonalność i równowagę, pragnącego przede wszystkim szukać kompromisu i porozumienia między różnorakimi frakcjami”. Taka postawa Obamy, służąca np. jednoczeniu społecznemu w USA, spotkała się z aprobatą i nadzieją na ukształtowanie się wielkiego ogólnoamerykańskiego ruchu społecznego. Ocenia się, że o ile w Stanach Zjednoczonych centrowość stanowi pewną tradycję, co nie oznacza możliwości długiego pozostawania „ponad podziałami”, o tyle w Europie bezideowa polityka interpretowana jest jako coś nowego, za czym może stać niezdolność polityków do podejmowania istotnych przedsięwzięćc ${ }^{27}$. Cechą świata postpolityki jest unikanie planowania rozwoju państwa i poprzestawanie na reagowaniu na bieżące zdarzenia. Postpolityka sprowadzana jest nawet do polityki drobnego bieżącego reagowania.

Zauważono też, że sprawowanie pospolitycznej władzy sprowadzane bywa do „kierowania wolą mas, nie pracą na ich rzecz, ale wykorzystaniem ich, zaprzęgnięciem do własnych celów. Metodą są pochlebstwa, półprawdy i gra na emocjach tłumu". Ta postpolityka, dla której reprezentatem miał być włoski premier Berlusconi, bywa postrzegana jako odświeżenie opisanego przez Platona mechanizmu manipulowania masami, którego jedynym celem jest posiadanie władzy. Ta populistyczna postpolityka traktowana jest zatem jako coś, co było normą przez wiele stuleci. Do odkrycia tego populistycznego wymiaru i wykrzywienia polityki

27 M. Walzer, Obamie nie uda się uciec od podejmowania radykalnych decyzji, Dodatek „Europa”, „Dziennik" 2009, 25-26 kwietnia, s. 4-5. 
w postpolitykę miało dojść po demokratycznym uświadomieniu sensu polityki. Wobec tego odejście od demokratycznego charakteru polityki przez postpolityków, $\mathrm{np}$. Berlusconiego, bywa opisywane jako swoiste odtworzenie tradycyjnego wymiaru polityki, a mianowicie „władza oddaje ludowi to, co ludowe - politykę rytualną, służącą gawiedzi”. Jeżeli zaś chodzi politykę realną, to jest ona „ukryta przed oczami większości”, a jej najważniejsze cele mają charakter egoistyczny.

Polityka ostentacyjnego cynizmu nie jest zatem zorientowana na ideały, jak powinno być, ale nawiązuje do aktualnego stanu zagmatwania, dotyczącego stanu ludzkiego myślenia i odczuwania. O skuteczności „prostych sztuczek” mało złożonych postpolityków ma świadczyć fakt, że mimo iż to oni są w ogromnym stopniu odpowiedzialni za wykształcenie warunków kryzysu w 2007 roku, to jednak także po zaniku tego kryzysu w 2010 roku utrzymali się przy władzy. W tym ujęciu postpolitycznym demokracja jawi się raczej jako zjawisko formalne, albowiem jest ona wypłukiwana ze swojej treści ${ }^{28}$. Wpływ na ten stan rzeczy przypisywany bywa w znacznym stopniu zjawisku „berlusconizmu”, na które składa się związek między wielkimi pieniędzmi a polityką, co „niemal wszędzie stanowi dziś ogromny problem”. W sytuacji zdominowania mediów przez władzę wybory zaczęły przypominać plebiscyt, zaś berlusconizm umożliwia istnienie demokracji plebiscytowej. Pewnymi przykładami adaptacji tego wzorca miałaby być demokracja rosyjska czy wenezuelska (w praktyce Hugona Chaveza) ${ }^{29}$. Zdominowanie stosunków publicznych przez postpolitykę na początku XXI w. niejednokrotnie odczytywane jest jako główny powód odchodzenia ludzi od polityki, gdyż utracili oni jej sens. W sytuacji kryzysu gospodarczo-finansowego z 2008 r. pojawiło się pytanie, czy infantylizacja relacji społecznych ustąpi przed prawdziwą polityką, skoro zabieganie o interesy jednostkowe, prywatno-partyjne, jest niewystarczające dla funkcjonowania zbiorowości, w której te interesy są i mogą być realizowane.

$\mathrm{Z}$ oceny, że wraz z postpolityką doszło do zepsucia demokracji i upadku polityki, do czego doprowadzili współcześni politycy (reprezentanci), wyprowadzono różne wnioski. Dowodzono, że następstwem postpolityki jest nieskuteczność debaty publicznej i rozkład władzy politycznej. Co więcej, w czasach upadku znaczenia idei poddano w wątpliwość przydatność polityków do odbudowania znaczenia polityki. Kwestionuje się przy tym sens demokracji reprezentatywnej, m. in. z uwagi na model partyjno-prywatnego uprawiania polityki. Wobec tego dowodzono też, że kryzys raczej uświadomił niesprawność i nieskuteczność „tradycyjnych” polityków, a powrót do polityki wiązany jest ze zbudowaniem demokracji lokalnej

${ }_{28}$ R. Krasowski, Kto jest wirtuozem postpolityki? Berlusconi, Tusk czy Kaczyński, Dodatek „Europa”, „Dziennik” 2009, 2-3 maja, s. 1.

29 A. Stille, Berlusconi na ruinach polityki, Dodatek „Europa”, „Dziennik” 2009, 2-3 maja, s. 2-3. 
(samorządowej) $)^{30}$. Postpolitycy, których cechuje brak koncepcji w obliczu rzeczywistości, zwłaszcza gospodarczej, opisywani są jako „bez reszty słabi”. Paradoksem jest to, że jako mistrzowie manipulacji wyborczych w świecie problemów rzeczywistych okazują się być ogarnięci niemocą. Mechanizmem zaradczym na tę niemoc ma być hiperaktywność, która jednak nie usuwała poczucia bezsiły rządzących. W tej sytuacji narasta atmosfera społecznego niepokoju, na którą rząd reaguje „polityką porządku" (Emmanuel Todd) ${ }^{31}$.

$\mathrm{Z}$ postpolityką wiązana jest mitomania, zauważana $\mathrm{w}$ wielu państwach. Ze względu na to, że władze państwowe nie są w stanie spowodować, aby obywatele respektowali stanowione przez nie ustawy ani same, z uwagi na braki finansowe, nie są zdolne do realizacji własnych zadań, toteż ocenia się, że politycy ciągle kłamią. Wyraża się to zwłaszcza w tym, że „produkują normy prawne, które i tak nie znajdą żadnego zastosowania, albo rozdają pieniądze, których nie mają. I w końcu - tak jak każdy kłamca - zaczynają okłamywać siebie: stają się państwem mitomanem, które nigdy nie stawia sobie pytania, czy to co mówi, ma jeszcze cokolwiek wspólnego z rzeczywistością". Władze oszukują w kwestii dochodów i wydatków, „okłamują wierzycieli, wyborców i same siebie i w końcu dochodzą do wniosku, że stać je na wszelkie szaleństwa. Aż pewnego dnia ktoś zażąda od nich prawdy - czyli prawdziwych pieniędzy"32.

Powyższe uwagi (a także i inne zawarte w opracowaniu) prowadzą do oceny, że postpolityka pojawiła się w warunkach upadku tradycyjnych nurtów politycznych i jest jednym z wymiarów epoki postmodernistycznej. W poszukiwaniach krytycznych tej wizji, to jest w projekcie popostmodernistycznym, trudno sobie wyobrazić powrót do tradycji wielkich ideologii z XX wieku reprezentowanych przez ruchy lewicowe i prawicowe. Przezwyciężanie postmodernizmu i postpolityki może podążać różnymi drogami, wśród których możliwa jest wersja humanistyczna. Dyskusyjne w tym wypadku są jednak kryteria humanizmu, które mogłyby stanowić podstawę oceny działań praktycznych i normatywnych osób rządzących.

Kapitalne znaczenie dla zrozumienia mechanizmu postpolityki ma odpowiedź na pytanie o jej filozoficzne uzasadnienie. Można zauważyć, że charakteryzująca postpolitykę bezradność i „ubezwłasnowolnienie” polityków wpisuje się w wizję neoliberalną. To wedle jej skrajnych założeń absolutnie wolny, zderegulowany mechanizm wolnego rynku (jego niewidzialna ręka w postaci mechanizmu popyt-podaż) jest

${ }^{30}$ M. Król, Po co nam premier i prezydent - jak długo będą w ogóle potrzebni? Jakie jest miejsce i znaczenie polityków w demokracji przyszłości, Dodatek „Magazyn”, „Dziennik. Gazeta Prawna” 2009, 27-29 listopada, s. M2.

31 E. Todd, Sarkozy wprowadził Francję w stan ideowej nieważkości, op.cit., s. 2-3.

32 J. Attali, Zachód zbankrutuje za 10 lat, Dodatek „Europa”, „Newsweek” 2010, nr 11, s. 6. 
w stanie poradzić sobie nie tylko z gospodarką, ale także z infrastrukturą, edukacją, nauką, służbą zdrowia itd. W tym świecie politycy nie pojawiają się jako aktywni uczestnicy przemian; to należy do przedsiębiorczego świata biznesu. Wszystko ma wartość i nadaje się do obrotu gospodarczego. Politycy, a jeszcze bardziej urzędnicy mogą spełniać tylko funkcje pomocnicze przy prawdziwych decydentach i kreatorach świata. Postpolityka w tym ujęciu jest swoistym aktem wykonawczym dostarczającym procedur i form do realizowania treści i interesów generowanych przez rynki. Prawdziwy świat finansów i gospodarki potrzebował zatem polityków jako formy i fasady dla realizacji swoich dążeń. A zatem rynki tym bardziej chwaliły polityka, im zgrabniej poruszał się w świecie PR, unikając konkretnych decyzji. Można powiedzieć, że „rozrywkowy”, ludyczny i niedecyzyjny polityk cieszył się zaufaniem mediów i rynków. Im lepiej potrafił celebrować urząd, posiadaną funkcję parlamentarzysty, tym bardziej mógł liczyć na przychylność realnej władzy kapitału.

\section{Ponowoczesny model upowszechniania demokracji}

Upowszechnianie demokracji wiązane też bywa z traktowaniem Unii Europejskiej jako wyrazu ponowoczesnego porządku. Uważa się, że ten nowy model charakteryzuje przede wszystkim rezygnacja $\mathrm{z}$ siły. Zdaniem Roberta Coopera wraz z powołaniem wspólnot udało się sprowadzić „wielką politykę wojny i pokoju do kwestii technicznych, takich jak taryfy handlowe czy system monetarny", chociaż na przyszłość model ten nie wydaje się wystarczający33. Ponowoczesny porządek Unii Europejskiej opisuje się jako taki, który nie jest kształtowany wedle ujęcia hegemonicznego bądź na zasadzie równowagi, lecz że ,jest wysoko rozwiniętym systemem wzajemnego ingerowania w sprawy wewnętrzne”. Rozwiązanie to wychodzi z założenia, że najważniejsze są interesy jednostek, a nie państw, co oznacza, że państwa systemu ponowoczesnego nie mają uzasadnienia do korzystania $\mathrm{z}$ sił zbrojnych we wzajemnych stosunkach.

Dostrzega on jednak ważny problem Europy, jakim jest jej otoczenie. O ile Europa jest systemem ponowoczesnym, o tyle otaczający ją świat jest nowoczesny (np. USA, Rosja) bądź przednowoczesny. W świecie tym „utrzymanie bezpieczeństwa wymaga równowagi, a niekiedy także użycia siły. Ponowoczesna Europa ma

33 R. Cooper, Czy Unia przetrwa w XXI wieku? (debata), Dodatek „Europa”, „Dziennik” 2008, 8-9 listopada, s. 2. 
z tym problem"34. Cooper zatem traktuje jako konieczne pojawienie się w dłuższej perspektywie tendencji demokratycznych w Rosji i Chinach.

\section{Modernizacja międzynarodowego ładu. Znaczenie państwa i prawa}

Wizjonerzy modernizacji współczesnego porządku międzynarodowego odnotowują, że procesom globalizacyjnym towarzyszy rozwój kulturowych odrębności, stereotypów i powiązań etnicznych, co m.in. negatywnie wpływa na globalizację. Dostrzegane są też przesłanki „uwiądu” tradycyjnego państwa i stawiana jest kwestia nowych form organizowania społeczeństw, zwłaszcza w warunkach globalizacji. Pojawiają się też próby poszukiwania płaszczyzn i środków sprzyjających modernizacji porządku międzynarodowego.

Jedna $\mathrm{z}$ koncepcji państwa w zglobalizowanym świecie sprowadza je do organizacji, jednej z wielu, która ma moc decyzyjno-regulacyjną. Z bardziej lokalnego punktu widzenia, to jest poprzez europejskie warunki globalizacji, dostrzegany jest zmierzch metafizyki państwa jako „kapsuły, w której najpełniej wyraża się nadzieja na racjonalizację życia społecznego", państwa, które od XIV w. poszukiwało podstaw dla ludzkiej pewności wobec rozwoju relatywizmu wartości. Z epoką Oświecenia państwo to uzyskało nowoczesne fundamenty. Charakterystyka tej wizji państwa odnajdywana jest zwłaszcza w opisie Maxa Webera, postrzegającego „państwo jako twór stanowiący ucieleśnienie procesu racjonalizacji, bo zdolny do przezwyciężania antynomii, napięcia między racjonalnością formalną (prawo, procedura) a racjonalnością substancjonalną ucieleśnioną w idei sprawiedliwości i rozwoju”. W państwie tym stanowiony suwerennie system prawa „miał kierować jednostki, niejako mimowolnie, ku realizowaniu wartości”.

Upadanie mitu państwa w zglobalizowanym świecie związane jest $\mathrm{z}$ tym, że nie ma w nim miejsca na dawniej pojmowaną jednoznaczną suwerenność oraz że brak w nim wcześniejszej jednorodności prawa. W ocenie Jadwigi Staniszkis kształtowany w przestrzeni państwa ,jednolity system prawny nie stanowi już wystarczającej gwarancji racjonalności działań i realizacji wartości”. W nowych warunkach odpada uznanie państwowego monopolu na władzę decyzyjną i normodawczą. Państwo okazuje się jedną $\mathrm{z}$ wielu struktur w tym zakresie, a sterowność $\mathrm{w}$ społeczeństwie okazuje się być nie tyle rezultatem możliwości władczych skoncentrowanych

${ }^{34}$ R. Kuźniar, Herold ponowoczesnej Europy, „Dziennik” 2008, 24 października, s. 19. 
w konkretnym centrum, ale jest pochodną ,jakości wewnątrzsystemowych powiązań między instytucjami oraz umiejętności metaanalizy i metaregulacji”. Profesor Staniszkis taką władzę, która nie ma podmiotów, a więc jest władzą „systemu nad samym sobą", postrzega obecnie jako mającą większe znaczenie niż ta władza, która jest demokratycznie wybraną polityczną reprezentacją. Wobec zmarginalizowania polityki pojawiają się wątpliwości co do metafizyki „racjonalności”, która powodowała, że jednolite prawo i polityczna procedura ujęte były w „kapsule państwa, gwaranta realizacji wartości". Wobec powyższego Staniszkis podnosi sprawę dalszych skutków tej ewolucji („zmierzchu metafizyki państwa”) w „europeizującej się” Europie i dochodzi do wniosku, że może nim być groźba „odspołecznienia”, albowiem polityczność postrzega jako zasadnicze spoiwo społecznej aktywności. Przypominając zaś, że nowoczesność odrzuciła korporatyzm i tradycjonalizm, zaś sekularyzacja ograniczyła wpływ religii, uznaje, iż po osłabieniu mitu państwa i znaczenia aktywności politycznej może nastąpić „przekształcenie społeczeństw we wspólnoty (a więc wzrost nacjonalizmów)" albo pojawienie się „hobbesiańskich” społeczeństw, które same kontrolują się i manipulują sobą za pomocą kultury. Jako trzecią możliwość Staniszkis podaje sytuację, w której „pogłębi się apatia, atomizacja i rozpad społeczeństw na rzecz »lokalności«i prywatności”35.

Mimo szeregu podobieństw tak daleko idących wniosków, brak prezentacji innych wizji czy choćby środków zapobiegawczych wobec zarysowanych niebezpieczeństw. Wspomniano, że globalizacji towarzyszy rozwój regionalizmów kulturalnych. Wobec tego stawiana jest kwestia, czy odrębności kulturowe prowadzące do „zderzenia cywilizacji” (Samuel Huntington) nie okażą się ograniczające, a nawet zgubne dla globalizacji, albowiem przeważą nad racjonalnością ekonomiczną. Jako interesujące dla integracji ładu międzynarodowego wskazywane są m.in. przykłady osiągnięć instytucjonalnych nowoczesnych państw. Uważa się, że instytucje te i reguły państwa prawnego mogą służyć jako swoiste wzory procesów modernizowania świata, opisywanych jako globalizacja. W każdym razie twierdzi się, że mimo iż różnice kulturowe wpływają na sprawy międzynarodowe, to jednak należy dostrzec integrującą siłę globalizacji oraz fakt, że modernizacja wywołuje w świecie pewną konwergencję instytucji i koncepcji rządzenia. Poszczególne kraje osiągały stan nowoczesności własną drogą, ich modernizacja zatem nie była rezultatem czynników zewnętrznych, stąd społeczeństwa mogą sobie nawzajem wiele zaoferować.

W ocenie Francisa Fukuyamy, bez względu na kulturowy punkt wyjścia, modernizacja ostatecznie nie uniknie konwergencji różnych rodzajów instytucji. Zwłaszcza skuteczność integracji gospodarczej i zaufanie w tym zakresie myśliciel wiąże

35 J. Staniszkis, Kryzys państwa, „Rzeczpospolita” 2003, 31 października - 2 listopada. 
$\mathrm{z}$ rozwojem jasnych reguł postępowania instytucji, a nie z powiązaniami charakterystycznymi dla relacji etniczno-kulturowych. Fukuyama dostrzegł, że współczesne państwo uporało się z paradoksem władzy, to jest, że „musi być dostatecznie silne, by móc egzekwować prawo i strzec porządku, ale jednocześnie musi się ograniczać w korzystaniu z przysługującej mu władzy, bo inaczej nie zazna długookresowego wzrostu gospodarczego". Państwo, które dobrze działa potrafi zatem nie tylko gromadzić władzę. Umiejętność samoograniczenia państwa, jakość instytucji i odpowiedni poziom prawa ma szczególne znaczenie dla zaufania inwestujących przedsiębiorstw, które to zaufanie jest podstawą współpracy zarówno na rynku wewnątrzkrajowym, jak i globalnym. Sporne są źródła tego zaufania.

Jeżeli chodzi o genezę zaufania, to odnajdywana jest ona w istnieniu tzw. rodzinnych więzów krwi. Ten typ zaufania rozszerzył się na większe grupy społeczne. Filozof dostrzega, że współcześnie zaufanie wynika nie tylko z przesłanek kulturowych (wspólne wartości, emocje, tradycja, historia), ale też ze wspólnoty interesów (może istnieć także między obcymi sobie kulturowo ludźmi, a u podstaw tego zaufania są instytucje). O ile pierwszy rodzaj zaufania ma miejsce zwłaszcza w sytuacjach kryzysowych, niepewności, to możliwości tego drugiego traktowane są jako trwalsze. Wynikać to ma $\mathrm{z}$ wrodzonej ludziom cechy zmierzania do realizowania własnego interesu i ten typ zaufania opisywany jest jako podstawa współzależności gospodarki światowej. Zatem znaczenie zaufania wynikającego ze wspólnoty interesów pozostaje w ścisłym związku z modernizacją krajów, a wypieranie zaufania tradycjonalnego sprzyja postępowi globalizacji.

Inaczej mówiąc, bezosobowe struktury, przejrzyste zasady i procedury umożliwiają rozszerzanie rynku poza granice określonych obszarów kulturowych. Bowiem formalne instytucje prawne i ekonomiczne, umożliwiając wzajemne zaufanie w biznesie, przezwyciężają formy kapitału społecznego ograniczone względami pokrewieństwa czy kulturowymi. Następuje przyspieszenie rozwoju zarówno w obszarze państw, jak i w układzie międzynarodowym. W powyższym ujęciu nadal istnieje potrzeba państwa, gdyż społeczeństwa oczekują pewnego ładu i praworządności. Nadto od państwa wymaga się, że będzie gwarantowało i w miarę sprawiedliwie rozdzielało różne zasoby i dobra publiczne. Wobec tego kwestią jest źródło sprawnego kierowania państwem, które - zdaniem filozofa - zagwarantuje, że władza będzie służyła rządzonym, a nie rządzącym. Do środków tych należą zwłaszcza wybory, organy władzy ze szczególną rolą parlamentu i sądów, a także instytucje społeczeństwa obywatelskiego i media ${ }^{36}$.

${ }^{36}$ F. Fukuyama, Kultura i interesy: zaufanie w globalnej gospodarce, Dodatek „Europa”, „Dziennik” 2007, 25 sierpnia, s. 34. 
W tym miejscu można nawiązać do projektu Kanta z pracy Wieczny pokój $j^{37}$, dotyczącego różnych poziomów prawa, to jest krajowego, międzynarodowego (Völkerrecht) i kosmopolitycznego (Weltbuergerrecht), oraz obowiązku (potrzeby) gościnności (światowej), czy też konieczności pokojowego współżycia ludzi (do czego nawiązał w swoich rozważaniach także Bauman). Szczególnie znacząca we wspomnianej pracy Kanta jest wizja gościnności, do której nie odnosił kwestii filantropii, ale prawa. Jak interpretuje Seyla Benhabib, gościnność ta nie jest sprawą cnoty społecznej, grzeczności czy wspaniałomyślności wobec innych, ale jest prawem przynależnym wszystkim ludziom jako uczestnikom światowej republiki. Ocenia, że podobnie kantowska jest argumentacja Hannah Arendt, która nie traktuje „przestępstw przeciwko ludzkości” jako naruszenia norm moralnych, ale jako naruszenie praw ludzkich w naszej osobie.

Z kantowskiego punktu widzenia nie do obrony jest taka odmowa pobytu, np. ofiarom wojny, która mogłaby doprowadzić do ich zniszczenia. Prawo gościnności dotyczy stosunku między obywatelami i obcymi, zajmuje przestrzeń między prawami człowieka, prawami obywatelskimi i politycznymi, między prawami ludzkimi w naszej osobie i prawami przypadającymi nam na tyle, na ile jesteśmy obywatelami specyficznej republiki. Prawo gościnności pociąga za sobą potencjalne prawne skutki, gdyż cechujące się dobrowolnością obowiązki państwa pojawiają się jako umocowane w kosmopolitycznym republikańskim porządku. Dostrzegany jest w tym dylemat dotyczący tworzenia quasi-prawnych, wiążących zobowiązań za pomocą dobrowolnego zobowiązania, przy jednoczesnym braku suwerennej władzy dysponującej przymusową egzekucją.

Kant wyróżnia dwie koncepcje suwerenności i ukazuje przejście z jednej do drugiej. W ujęciu tym suwerenność nie oznacza ostatecznej, arbitralnej władzy na pewnym terytorium. Jej przejawem nie jest państwo karzące obywateli za naruszenie prawa, zamykające granice, ograniczające swobodę gospodarczą, słowa, akty zrzeszania się; nie pojawia się w ramach określonej społeczności państwowej. Nie jest więc suwerennością żenująca praktyka obywatelskich i kulturowych sankcji, które wymuszają określone zachowania. Kosmopolityczne reguły pojawiają się nie między państwami (to jest prawo traktatów), ale w sytuacjach, gdy państwowe i niepaństwowe podmioty wchodzą $\mathrm{w}$ relacje $\mathrm{z}$ ludźmi, którzy nie są uczestnikami swej własnej polityki. W kantowskiej wizji świata ludzie są uczestnikami obywatelskiego porządku i pojawiają się w sytuacji prawowitego stowarzyszenia każdego z każdym. Przy czym warunków tego współistnienia filozof nie zrównywał z ustrojem

37 W tytułach poszczególnych artykułów pojawiały się myśli, że: 1) konstytucja obywatelska państw powinna być republikańska, 2) prawo narodów ma znaleźć się u podstaw federacji wolnych państw, 3) prawo obywatelstwa światowego powinno być ograniczone do warunków uniwersalnej gościnności. 
republikańskim, gdyż kosmopolityczni obywatele potrzebują konkretnej republiki, aby być w ogóle obywatelami. Filozof nie godził się zatem z wizją „światowego rządu” wynikającego z „uniwersalnej monarchii”, którego cechą byłby „bezduszny despotyzm”. W federacji państw dostrzegał stałą możliwość realizowania obywatelstwa w ramach powiązanych wspólnot.

W wizji tego myśliciela (a także Arendt i Jaspersa) Seyla Benhabib odnajduje dążność do tworzenia norm, które nie tylko wiążą jednostki, ale i podmioty zbiorowe (np. państwa, rządy). Prawo do uniwersalnej gościnności oznacza więc nałożenie obowiązku na politycznego suwerena poprzez zakazanie mu odmowy, np. azylu, jeżeli odmowa ta prowadziłaby do zniszczenia ludzi. Koncepcja przestępstwa przeciwko ludzkości oznacza niedopuszczalność angażowania się sprawujących władzę $\mathrm{w}$ akty przestępcze popełniane przeciwko ludności cywilnej czy też w działania dyskryminujące z jakichkolwiek przyczyn. W podejściu tym chodzi nie tylko o zasady indywidualnego postępowania, ale i o wykreowanie zasad publicznej moralności i instytucjonalnej sprawiedliwości. Projekt ten wychodzi poza pozytywistyczny wzór zakazów i nakazów opublikowanego prawa. Kantowska gościnność przedstawiona jest jako prawa człowieka, które przekraczają wszelkie granice.

Wśród problemów dotyczących tej wizji dostrzega się zwłaszcza napięcie między oczekiwaniem kosmopolitycznej sprawiedliwości, prawami człowieka i republikańskim rządem (samorządem). Jeżeli chodzi o legitymację nowoczesnego demokratycznego suwerena, to odnajdywana jest ona nie tylko w jego akcie konstytucyjnym, ale także ma wynikać ze zgodności tego aktu z uniwersalnymi prawami człowieka, które w pewnym sensie poprzedzają wolę suwerena i w myśl których suweren dokonuje samozwiązania. Wspomniany stan między żądaniami uniwersalnych praw człowieka a partykularną kulturową tożsamością społeczności tworzy, jak zaznacza Benhabib, między nimi swoiste napięcie, ale też odnajdywane są tu warunki kształtowania demokratycznej legitymacji. W pojawiającym się tu paradoksie demokratycznej legitymacji chodzi o to, że republikański suweren ma związać swoją wolę przez szereg zobowiązań, będących zbiorem formalnych i materialnych norm określonych jako tzw. prawa człowieka. Rozwiązanie tego stanu w republice nie jest w pełni możliwe. W każdym razie demokratyczne działanie w imieniu uniwersalnych zasad, które są wpisywane w poszczególne wspólnoty obywatelskie, określane bywają (za Jürgenem Habermasem) jako „Janusowe oblicze współczesnych narodów”.

W tym zakresie dostrzega się znaczący instytucjonalny rozwój praw człowieka, począwszy od Deklaracji Praw Człowieka Narodów Zjednoczonych z 1948 r., po wpływ różnych współzależnych i w różnym stopniu zachodzących na siebie globalnych i regionalnych porządków praw człowieka oraz prawa zwyczajowego. Z punktu widzenia procesów globalizacji pozytywnie oceniane jest przejmowanie 
przez systemy prawne praw człowieka, zwłaszcza w sytuacji uznawania przewagi prawa międzynarodowego w stosunku do krajowego. W każdym razie rozszerzanie kosmopolitycznych reguł (od tych, które dotyczą zbrodni przeciwko ludzkości, do reguł dotyczących uchodźctwa, azylu czy imigracji) spowodowało ujęcie demokracji liberalnych w sieć zobowiązań dotyczących uznawania różnych żądań. Wzrastają zwłaszcza trudności z usprawiedliwieniem różnych wykluczeń i ograniczeń dokonywanych przez prawodawcę, albowiem mają wyrażać wolę obywateli. Ale nie jest to wyłącznie sprawa na poziomie krajowego podejścia konstytucyjnego, w tym w zakresie równoważenia władzy organów państwa, ale także na poziomie przestrzeni międzynarodowej. Wniosek Benhabib jest taki, że demokracje muszą nauczyć się negocjacji między rozszerzającym się obszarem norm kosmopolitycznych a regułami demokratycznej wspólnoty ${ }^{38}$.

\section{Zakwestionowanie postnowoczesnego świata bez wyraźnych kryteriów. Postponowoczesność}

\subsection{Zmierzch tzw. epoki nowoczesności i potrzeba neoglobalizacji}

Po raz pierwszy zakwestionowanie tradycji porządku międzynarodowego opartego na państwach narodowych pojawiło się po drugiej wojnie światowej, chociaż pewnych antycypacji można doszukiwać się $\mathrm{w}$ wizji wersalskiej po pierwszej wojnie światowej. W połowie XX w., pod wpływem projektów świata Zachodu, wykształciło się wiele instytucji międzynarodowych, z ONZ na czele, a w Europie, oprócz rozwiązań międzynarodowych - Rada Europy, pojawił się całkowicie nowatorski projekt Wspólnot Europejskich (obecnie UE). Pod koniec XX w. coraz wyraźniejsze były sygnały o powolnym zmierzchu tzw. epoki nowoczesności na świecie, zwłaszcza na Zachodzie, której instytucje uzyskały formę i treść przed półwieczem. Dało się dostrzec, że w różnych miejscach na świecie następuje osłabienie i zanik pewnych tradycyjnych instytucji i że w różnym tempie oraz zakresie wykształcają się nowe relacje, następują zmiany w sferze ekonomicznej, społeczno-politycznej czy kulturalnej.

38 S. Benhabib, On the philosophical foundation of cosmopolitan norms, w: Law and legal cultures in the 21st century: diversity and unity, red. T. Gizbert-Studnicki, J. Stelmach, s. 66-68; I. Kant, Zum ewigen Frieden: ein philosophischer Entwurf, 1795; J. Habermas, The European Nation-State: on the past and future of sovereignty and citizenship, 1998. 
Te i inne przemiany określano mianem postnowoczesności, postindustrialności, ponowoczesności czy globalizacji. O zmianach tych można powiedzieć, że zaczęły wpływać zwłaszcza na wykształcanie nowej ograniczonej roli państw, że powszechnie uznano, iż dla rozwoju i spokoju społecznego liczy się przede wszystkim ogromny wzrost gospodarki, zwłaszcza w wymiarze globalnym. Osłabianiu dominującej koncepcji państwa narodowego, z jego misją odwołującą się w swych założeniach do wieku XIX, sprzyjała nie tylko globalizacja finansowo-gospodarcza, ale także globalizacja wszelkich innych relacji, np. naukowych i kulturowo-edukacyjnych. Nadto ekonomizacja $\mathrm{z}$ hasłem nieograniczonego wolnego rynku, zwłaszcza o wymiarze globalnym, wpłynęła na tendencje prywatyzacyjne w różnych sferach, nawet $w$ dziedzinach tradycyjnie publicznych. Opuszczanie zaś tej sfery publicznej przez państwo narodowe powodowało nowe następstwa w postaci rozmywania się więzów kulturowych łączących obywateli ${ }^{39}$.

Powyższa tendencja zderzyła się z dynamicznymi następstwami kryzysu 2007 r., który przyczynił się do jeszcze wyraźniejszego pogłębienia rozważań nad nowym sensem państwa i prawa, zwłaszcza w zakresie finansów i gospodarki globalnej. Sytuacja kryzysu uświadomiła także konieczność przyspieszenia budowy nowego ładu międzynarodowego, w ramach którego znaczący będzie prawny porządek dotyczący globalnej gospodarki i globalnej ochrony biosfery. Pojawiła się ocena, że na świecie dokonuje się skok w XXI wiek. Wspomniany zryw, czy też skok ku nowemu uzasadniały spostrzeżenia o niesłychanej dynamice przemian, dla oceny których charakterystyczne może być zdanie o świecie przedkryzysowym: „to, co dwa lata temu zdawało się przyszłością, teraz zdaje się przeszłością; co zdawało się nowoczesne, okazuje się anachroniczne. Dzieje się to szybciej niż kiedykolwiek”. Pojawił się nowy „klub” podmiotów decydujących o sprawach międzynarodowych, zaś w stosunku do państw pielęgnujących wizje konserwatywne, jak np. Polska, sformułowano ocenę, że nie biorąc udziału w dokonujących się zmianach, nie kształtując ich - skazują się "na peryferyjność, wieczne imitacje, nieustanne doganianie innych”, na ciągłe dostosowywanie się do nich. Znaczącą przeszkodą w twórczym procesie zwrotnych przemian okazuje się więc mentalność społeczeństwa, tkwienie w swoistej „prowincjonalności”"

Zbliżoną ocenę wydobyto także z porównania podejścia do problemu klimatu na Ziemi prezentowanego przez tzw. stare i nowe kraje UE. „Stara” UE przygotowała i podjęła realizację nowych celów służących biosferze, co oznacza nacisk na nadanie gospodarce charakteru proekologicznego, z jednoczesnym zachowaniem

39 M. Kwiek, Filozofia - demokracja - uniwersytet: wyzwania epoki globalizacji, w: Filozofia a demokracja, red. P.W. Juchacz, R. Kozłowski, Poznań 2001, s. 195, 196.

40 J. Żakowski, Polski błąd, „Gazeta Wyborcza” 2009, 28 grudnia, s. 7. 
oszczędności ekonomicznej. Podobny projekt finansowania czystych technologii przyjęły Stany Zjednoczone, zaś Chiny już w 2009 r. dowodziły, że zaczynają kierować się oszczędnością i zielonymi technologiami. Również kraje arabskie zwróciły uwagę na problem nowych źródeł pozyskiwania energii, czego dowodzi np. zawarcie umów na budowę wielu elektrowni nuklearnych. Natomiast pod koniec 2009 r. szereg nowych państw UE, z Polską na czele, jak oceniono, zmierzały w innym kierunku, tj. $\mathrm{w}$ kierunku utrzymania pewnego status quo (pozostawania w obszarze państw imitujących), a zatem rezygnowały $\mathrm{z}$ szansy włączenia się $\mathrm{w}$ tworzenie nowych technologii ${ }^{41}$.

W coraz częstszych ocenach pierwszego dziesięciolecia XXI w. na pierwszy plan wysuwają się takie zagadnienia, jak: biosfera, nowa ekologiczna gospodarka globalna, odchodzenie od modelu państw jako wyłącznych gospodarzy polityki krajowej i międzynarodowej oraz konstrukcja suwerenności „mocarstw” czy „supermocarstw”. Problemy te odsunęły uwagę ogółu skupioną dotychczas na państwach, ich wielkich celach i rolach, na konserwowaniu XIX-wiecznej wizji narodu czy na systemach politycznych obarczonych kształtem XIX-wiecznego sporu ideologicznego, przekładającego się na obrazy i języki lewicy i prawicy. Zrozumiałe, że wraz z wykształcaniem nowych globalnych uporządkowań coraz częściej będzie dochodziło do konfliktów z nieelastycznymi kulturami chroniącymi się za parawanem „historycznych” prawd, za wizją konstytucyjnych (niejednokrotnie prowincjonalnych) praw narodu i służącymi im wykonawczymi regulacjami państwa, z jego zakrzepłymi strukturami i konserwatywnymi instytucjami publicznymi.

\subsection{Postponowoczesność: przyczyny, cechy (etyka, racjonalność)}

\subsubsection{Postponowoczesność jako krytyka ponowoczesności}

Znaczenie dla aktualnych ocen mają projekty myślowe określane jako postponowoczesne i charakteryzowane w oparciu o formułowaną przez nie krytykę nihilizmu postmodernistycznego (Daniel Bell) ${ }^{42}$. Interesująca jest także opinia Bella dotycząca przełomu XX i XXI wieku jako „wielkiego historycznego przyspieszenia”. Realia tego okresu (np. upadek komunizmu, masakry w Rwandzie i Darfurze, zamachy z 11 września, wojny w Afganistanie i Iraku) zderzyły się z postmodernizmem, który „uległ rozproszeniu”. Ludzie przestali myśleć wyłącznie kategoriami postmodernistycznymi, w których brak jakichkolwiek kryteriów osądu. Zakwestionowano

\footnotetext{
41 P. Świeboda, Klimat znowu kochamy inaczej, „Gazeta Wyborcza” 2009, 19-20 grudnia, s. 22.

42 Por. pracę Daniela Bella Kulturowe sprzeczności kapitalizmu z 1976 roku.
} 
myślenie uznające, że nie ma znaczenia to, czy coś jest prawdziwe, czy nieprawdziwe. Zdaniem socjologa etyka przestaje być traktowana jako jakiś „staroświecki sposób myślenia, który po prostu wyśmiewano". Powraca ona w pytaniach: Jakiego rodzaju zobowiązania mam wobec innych ludzi? Czy jestem im cokolwiek winien?

Kwestie te dotyczą także świata kapitalizmu, który w swojej „nagiej” formule wyraża myśl, że „nie mamy absolutnie żadnych zobowiązań wobec innych ludzi, że możemy ich zostawić bez jedzenia i dachu nad głową". W przypadku korporacji oznacza to, że nie ma ona obowiązku wspierać celów społecznych, że „nie ma też żadnych obowiązków wobec swoich pracowników. Cóż z tego, że pracowali w niej 20 czy 30 lat - i tak można ich wyrzucić z pracy z dnia na dzień. W nagim kapitalizmie korporacja ma jedynie obowiązki wobec udziałowców - osób, które pojawiają się i znikają w mgnieniu oka, w poszukiwaniu jak najszybszych i jak największych zysków. Coraz częściej wydaje się nam, że takie podejście jest nie do przyjęcia. Tu także powraca kwestia etyczna"43. Okazało się, że postmodernistyczna wizja braku kryteriów sądzenia nie sprawdziła się, gdyż konieczne jest rozstrzyganie, czy obecne działania odpowiadają całemu kontekstowi kulturowemu, czy historycznemu.

Postmodernizm okazał się wizją antyoświeceniową, a jego sens zawarto w antyintelektualnych, antypoznawczych częściach „modernizmu z pochwałą konsumeryzmu - stąd atak na elitaryzm sztuki, próba zniesienia podziału między tym, co wysokie i niskie, pochwała kiczu”. Dążności te uzyskały radykalny charakter zwłaszcza tam, gdzie „elity utraciły jakiekolwiek poczucie spójności swoich poglądów - ich brak zakorzenienia w tradycyjnej moralności czy tradycji liberalnej sprawił, że przestały dostrzegać granicę między tym, co dozwolone i niedozwolone". Postmodernizm nie okazał się zatem wizją wyzwoleńczą, ale faktycznie skierowany np. przeciwko nauce okazał się przeciwnikiem wolności. Dowodząc tego, Bell trafnie zauważa, że w nauce nie ma osoby, której autorytet oznacza prawdę. Uwarunkowane jest to specyficznymi cechami projektu, jakim jest nauka; ma ona charakter prawdziwie wyzwoleńczy, jest ,jedyną permanentną rewolucją w dziejach ludzkości, ponieważ jej celem jest podważenie ustaleń dokonanych przez poprzedników”"44.

\subsubsection{Cynizm postnowoczesności}

Nowa kwestia etyczna przeciwstawiana jest triumfującemu na początku XXI w. cynizmowi. Ta upowszechniona cecha rozwiniętych społeczeństw nie ma jednego znaczenia, ale dostrzeżono, że społeczeństwa Zachodu odznaczają się nią zwłaszcza, gdy chcą uniknąć debaty czy krytyki politycznej. Postawa cyniczna nie pojawiła

43 D. Bell, Wojna kultur zastąpiła walkę klas, w: Idee z pierwszej ręki..., op.cit., s. 226.

${ }^{44}$ Ibidem, s. 226-228. 
się bez przyczyny. Interpretowana jest jako następstwo istotnego zakwestionowania przez współczesność oświeceniowej wizji ufającej postępowi naukowo-technicznemu i racjonalizmowi. Zwłaszcza doświadczenia totalitaryzmów XX wieku podważyły wiarę w oświeceniowe obietnice emancypacji, równości i sprawiedliwości jednostki. Ideały te okazały się fikcją, ale fikcja ta jest ciągle podtrzymywana, co jest wyrazem cynizmu wobec faktu, że rzeczywistość jest odmienna. Charakterystyczna jest tu myśl filozofa Petera Sloterdijka, że „działanie na przekór dostępnej lepszej wiedzy stało się dziś prawem powszechnym” i cynizm ten jest „oświeconą fałszywą świadomością”, która panuje (ma miejsce swoisty „cyniczny” konsensus nowoczesności).

Wspomniany cynizm Sloterdijk odkrywa np. w poglądzie, że ludzie na Zachodzie żyją w egoistycznym, chciwym kapitalizmie, w którym wytwarza się konflikt klasy wyzyskiwanej i wyzyskującej. To stanowisko traktuje on jako sprzeczne $\mathrm{z}$ dostępną wiedzą, wedle której prawdziwa linia konfliktu usytuowana jest między szczególnie efektywną grupą płacącą najwyższe, progresywne podatki a nieefektywną masą. W ujęciu tym mitem okazuje się „złodziejski” charakter kapitalizmu, albowiem prawdziwy wyzysk dotyczy produktywnych grup społecznych przez pozostałych, żyjących na ich koszt i dokonujących zadłużania przyszłych pokoleń („grabieży przyszłości”). Pojęcie podatków na rzecz dobra ogółu oznacza eksploatowanie najefektywniejszych ${ }^{45}$. Już wcześniej Sloterdijk dostrzegał, że nie ma wartościowych spraw ani „lewicowych”, ani „prawicowych”, albowiem fala cynizmu likwiduje sens idei, wprowadzając je w świat iluzji. To bycie „mądrzejszym” w społeczeństwie, charakterystyczne dla cynika, filozof odkrywa w postawie najlepszego przystosowania do istniejących warunków.

Kwestią dyskusyjną jest tutaj obszar wsparcia cynizmu i upowszechniania go jako czegoś poprawnego. Filozof obciąża tym media, które potwierdzają iluzoryczność wartości: sprawy ważne rozmywają w potoku trywialności i nachalności, spłaszczają tragizm ludzkich losów, sprowadzając wszystko do newsów, o których szybko się zapomina. W ocenie myśliciela dodatkowa przewrotność, paradoksalność tego stanu wywoływana jest obłudą mediów przybierających szaty obrońcy moralności i wartości człowieka. Polega to na wykorzystywaniu przez media ludzkich emocji i sentymentów do budowanej na ich podstawie wizji świata. W takiej sytuacji twórcy mediów mogą swobodnie moralizować społeczeństwo i zarzucać je newsami i sensacją, by już „bez przeszkód [...] wywierać swe uwodzicielskie i ogłupiające oddziaływanie". Sloterdijk jest pesymistą co do współczesnej możliwości przełamania medialnego cynizmu w drodze krytyki. Jest tak dlatego, że uzasadnienia i argumenty krytycznej debaty media opanowały, obezwładniły i dokonały ich instrumentalizacji

45 P. Buras, Bunt filozofa, bunt mieszczan, „Gazeta Wyborcza” 2009, 28-29 listopada, s. 24. 
pod kątem własnych potrzeb. Co ważne, sączący się wprost i pośrednio cynizm mediów zainfekował ich odbiorców ${ }^{46}$. Sensacja, zwłaszcza ta, której treścią są zagrożenia, stała się na początku XXI w. szczególnie istotnym środkiem do manipulowania społeczeństwem.

\subsubsection{Postmodernistyczny duch jako zagrożenie dla liberalnej kapitalistycznej demokracji. Powrót do rozumu}

Rozważania filozoficzne przyczyny kryzysu finansowo-gospodarczego i społecznego z 2007 roku wiążą z następstwami ducha postmodernizmu - z jego „systematycznym ukrywaniem zagrożeń” (Jean-Claude Trichet) czy też „panglossjańskim mechanizmem kapitalizmu, który wszystko uważa za dozwolone, jako że żyjemy na »najlepszym ze światów«” (Paul Krugman). W stanowisku tym André Glucksmann łatwo odnajduje „zgubną euforię postmodernistycznej egzystencji, ponad dobrem i złem, poza prawdą i fałszem”. W nowym „pojednanym świecie” dochodzi do triumfu etosu czynu, którego nie ograniczają już żadne obawy ani wyrzuty sumienia, ale jest on "pełen wiary w postmodenistyczne hasła, które głoszą, że Bóg umarł, a wkrótce umrą i demony". Charakterystyczne dla wcześniejszej gospodarki rynkowej relatywne traktowanie dóbr (towary wymienne) i tolerancyjne podejście do dobra (względność wartości w warunkach pluralizmu) uległy w nowych warunkach stopieniu w jedno. Uznano, że „wszelkie ryzyko można zredukować do zera, dzieląc się nim i wzajemnie zabezpieczając”, co w interpretacji Glucksmanna „oznaczało radosne panowanie »myśli pozytywnej «". Koncepcje lewicowe i prawicowe zasadniczo zgodnie uznawały „nieuchronne zwycięstwo demokracji na naszej planecie, pokój i harmonię, które obiecuje nowy, wielobiegunowy porządek świata”.

Katastrofa na światowych rynkach finansowych, a także rosyjska interwencja w Gruzji ujawniły zgubne rezultaty owego euforycznego bezkrytycznego nastawienia pozytywnego. Winą za stan kryzysu Glucksmann nie obarcza banków, gdyż jego zdaniem taka ocena nie ukazywałaby pełni prawdy, a zaledwie jej część. Łatwo bowiem obwiniać za kryzys różne „szaleństwa” jakichś nieludzkich systemów czy opętanych żądzą zysku spekulantów rynkowych. Glucksmann twierdzi, że źródłem kryzysu jest nie tyle nadużycie zaufania przez instytucje finansowe, ile fakt, że „opinia publiczna i politycy, w równym stopniu jak finansiści dali się uwieść syrenom postmodernizmu". Formułując propozycje wyjścia $z$ tej sytuacji, filozof nie kreśli wizji nowego społeczeństwa, opatrznościowego działania rządów czy matematycznych wynalazków.

46 M. Warchala, Sloterdijk - filozoficzny prześmiewca, „Dziennik” 2007, 30 października, s. 20. 
Odwołuje się tymczasem do cytatu z Platona: „Istnieje przecież chyba jedna tylko moneta prawdziwa, za którą wszystko to wymienić należy: rozum" ${ }^{37}$.

Powyższa uwaga podejmuje sprawę wizji postponowoczesnej. Można powiedzieć - przy zachowaniu dotychczasowej logiki zdarzeń, w której kolejne, coraz to „nowocześniejsze" teorie filozoficzne zachowywały krytyczny stosunek do swoich poprzedniczek - iż jest prawdopodobne, że projekty postponowoczesne będzie cechowała próba poszukiwania piękna, racjonalności, harmonii, sensu i statyki. Możliwe, że przyszłe podejścia do państwa i prawa będą miały wymiar ekonomiczny, legitymizujący się skutecznością ${ }^{48}$. Możliwy jest też jakiś konwencjonalizm, np. w rezultacie oceny, że wobec tego, iż postmodernistyczna „niszczycielska siła antyfundacjonizmu i sceptycyzmu pozostawiła po sobie zgliszcza”, to niemożliwe jest przywrócenie „do życia uniwersalnych idei Zła ani Rozumu". Wówczas pozostanie jedynie skierować się do tego, „co podstawowe i właściwe każdemu żywemu stworzeniu: do instynktu samozachowawczego. Każdy chce przetrwać w obecnej formie. I to mógłby być punkt wyjścia dla postponowoczesnej koncepcji prawa"49 i państwa. Inaczej mówiąc, jeżeli społeczeństwo chce przetrwać, to musi zastanowić się, co jest do tego konieczne i próbować świadomie to realizować.

\section{Postmodernity. State in postmodern perspective (selected detailed issues)}

Evaluation of the present human attitude towards world and society seems to be similar to the fears caused by the destruction of earlier visions of permanent and meaningful world that have taken place during Enlightenment. The visions of real dangers are accompanied by reflections on conditions of survival. At the same time the hope put on the ideology of self-regulating neoliberal market is fading and is being treated as a sort of masquerade. New thinking, "post-postmodern”, takes on the question how it should be so the World is preserved. And so emerges the awareness of the necessity of projects which will propose a future more stable

47 A. Glucksmann Zacznij myśleć mieszczaninie, „Gazeta Wyborcza” 2008, 15-16 listopada, s. 25.

${ }^{48}$ M. Zirk-Sadowski, Postmodernistyczna jurysprudencja?, w: Z zagadnień teorii i filozofii prawa, op.cit., s. 24.

${ }^{49}$ A. Kozak uznając, że „wszystko jest konwencją”, opowiadał się za powrotem do koncepcji konwencjonalności, zaś reprezentującą ją teorię pozytywną miałyby cechować: „indywidualizm, instytucjonalność, obrona podmiotowości, deliberatywność i zasada uzasadnionej przezorności” (A. Kozak, Postponowoczesna koncepcja prawa, w: Z zagadnień teorii i filozofii prawa..., op.cit., s. 76-77). 
compared to the postmodern model of maximum, cheap, accidental and current consumption, bureaucratic practice of neo-competition and a postpolitcs of small contemporary reactions manipulated by media hype. Post-postmodernity emerges today as minimalistic idea about fixing the most important faults of today according to the convention and ethics navigating according to the reason that is rooted in science.

\section{La postmodernité. L'État dans la perspective postmoderne (plusieurs questions détaillées)}

Une évaluation de l'attitude des gens envers le monde et la société semble être similaire à des craintes suscitées par la destruction des visions antérieures d'un monde permanent et significatif qui a eu lieu au cours du siècle des Lumières. Les visions de dangers réels sont accompagnées par des réflexions sur les conditions de la survie. Dans le même temps, l'espoir mis sur l'idéologie néolibérale de l'auto-régulation du marché s'estompe et ce mécanisme est considéré comme une mascarade. Une nouvelle réflexion, " post-postmoderne ", aborde la question de savoir comment il devrait être pour que le monde soit préservé. Cela crée une prise de conscience de la nécessité des projets qui offrent un avenir plus stable par rapport au modèle postmoderne caractérisé par une consommation maximale, pas cher, accidentelle, aux pratiques bureaucratiques de néo-concurrence et à la post-politique manipulée par le bruit médiatique. La post-postmodernité semble être une idée minimaliste concernant la correction des défauts les plus importants des temps modernes conformément à la convention et à léthique guidées par la raison, ancrée dans la science. 